\title{
EFFECT OF FOLIAR SPRAY WITH SOME FERTILIZERS AND CHEMICALS ON VEGETATIVE GROWTH, YIELD AND ITS RELATION TO POWDERY MILDEW DISEASE OF SQUASH PLANTS CAUSED BY Erysiphe cichoracearum \\ El-Shabrawy, R. A.* and A. A. El-Kafrawy** \\ * Veget. Dept, Hort. Res. Institute. Agric. Res. Center, Giza, Egypt. \\ ${ }^{\star *}$ Plant Pathology. Res. Inst . Agric. Res. Center, Giza, Egypt.
}

\section{ABSTRACT}

In order to save the Egyption ecosystem from pollution with pesticides, under laboratory conditions . application of potassin $(\mathrm{P})$, mixed with $(\mathrm{N}+\mathrm{P}+\mathrm{K})$, potassium sulphate and potassin $(\mathrm{N})$ at $800 \mathrm{ppm}$ in vitro decreased conidia germination and length of germ tube of Erysiphe cichoracearum. However the least effective treatment was Urea $(\mathrm{N})$. Under field condition, all tested macroelements as foliar spray reduced powdery mildew disease severity . Application of $(N+P+K)$, potassin- $F$, potassium sulphate and calcium supper phosphate resulted the best effects. Disease severity was reduced to $18.14,18.95,19.78$ and $20.96 \%$ respectively compared with control $63.65 \%$. Observed results clear The Topase and sulpher micronized fungicide gave the best disease control. Two field experiments were carried out on squash $\mathrm{cV}$. Eskandrani in the two summer season 2003 and 2004 to study the effect of foliar application with Urea $1 \%$, calcium super phosphate $1 \%$, potassium sulphate $1 \%+$ potassium sulphate $1 \%$, potassin- $\mathrm{N} 2.5 \mathrm{ml} / \mathrm{l}$, potassin- $\mathrm{F} 2.5 \mathrm{~cm} / \mathrm{l}$, Topas $0.25 \mathrm{ml} / \mathrm{l}$ and sulpher $2.5 \mathrm{gm} / \mathrm{l}$ on growth, sex expression, yield, chemical composition and disease severity of powdery mildew of squash plants. The results revealed that, vegetative growth (number of leaves, plant height, fresh and dry weight ) were significantly increased by foliar application with all treatments compared with control .Spraying squash plants with Topase gave the highest values of number of fruits per plant, morever, foliar spray with salpher micronized gave the highest values of fresh and dry weight plants. Average fruit weight, early yield and total were obtained by foliar application squash plants with Urea $1 \%$ + calcium super phosphate $1 \%+$ potassium sulphate $1 \%$ and potassin- $\mathrm{N} 2.5 \mathrm{ml} / /$. The chemical composition of the leaves revealed that different treatments used significantly increased $\mathrm{N}, \mathrm{P}$ and $\mathrm{K}$ compared with control. In general, it can be stated that foliar application with Urea $1 \%+$ calcium super phosphate $1 \%$ + potassium sulphate $1 \%$ and potassin- $\mathrm{N} 2.5 \mathrm{ml} / \mathrm{l}$ were recommended to raise squash production under the environment condition of this investigation .

\section{INTRODUCTION}

The cucurbits are world important vegetable crops, generally they are attacked by many pathogens either in the open field or under covered agriculture conditions resulting in great economic losses i.e. Erysiphe cichoracearum the causal organisms of powdery mildew (maximlian, et al . 1976). However good control of these disease can be achieved by chemical control products, they cause hazardous on the environmental and consumers (javoraska, 1978). Limit the use of these pesticides emphasize the need altrenative methods to control plant disease .(Wilson et al. 1987).Summer squash ( cucrbito pepo I .) is one of the most vegetable crops in Egypt . Total cultivated area exceeds 95736 feddan in 2004 , which yielded 729772 tons, with an average 7.62 feddan were devoted to squash 
plantation. Department of Agricultural Economies and statistics, Ministry of Agriculture, ARE, 2005. Plant nutrition is one of the primary factors, which play arole in vertically raising the yield of vegetable crops, especially those of upright vegetation like squash. Many factors are known to affect squash growth, Sex expression, Yield and its quality . Foliar application of N, P and $\mathrm{K}$ fertilizers are of great importance in these conditions. There are many factors that affect the availability of $\mathrm{P}$ and $\mathrm{K}$ in soils. Mengel and kirkby (1987) reported that clay content probably contributed more fixation of $\mathrm{P}, \mathrm{N}$ and $\mathrm{K}$ by clay minerals, leading to reduction of their availability and thus lower available concentration in soils. Amberger (1993) reported that phosphorus is quite immobile in soils with neutral or high $\mathrm{PH}$ and appears in more or less stable ca phosphate. Added phosphate does not move more than $2.3 \mathrm{~mm}$ from the fertilizers praticle and its precipitated rapidly to dicalcium phosphate $(\mathrm{Ca} \mathrm{H}$ $\mathrm{PO}_{4} . \mathrm{H}_{2} \mathrm{O}$ ) or octocalcium phosphate, emtirly unavailable to crops. Smmoro (1997) reported that in soils which are rich in calcium and are alkaline in reaction, phosphate added as fertilizers are converted to less available from of calcium compounds. Many investigators reported that foliar application with NPK increased vegetative growth, sex expression, yield of squash plants, EL. Sayed et al., (1992) found that spraying of squash plants with 0.04 $p$ as $\mathrm{KH}_{2} \mathrm{PO}_{4}$ increased the total fruit yield. Also, Hanafy Ahmed (1997) found that spraying squash plants with Urea $(1 \%)$, calcium super phosphate $(1 \%)$ and potassium sulphate $1 \%$ increased significantly number of female flowers per plant and the percentage of femaleness and increased fruit yield. Powdery mildew cucurbits is endemic and major disease in Egypt, caused by Erysiphe cichoraceam which may cause losses reach to 30-80 from fruit yield of squash when the percentage of infection reaches to $50-100 \%$ (Curger 1974 and EL. Nagar et al. , 1991). The disease control can be achieved by using resistant cultivars and or chemicals . several fungicides. Recently become available for the control of powdery mildew (Gruzdyen 1980 and Isamail et al. 2003) on squash. Most of these investigators studied the effect of fungicides on controlling the growth and spread of fungi without determining their effect on plant growth and production. This work aims to study the effect of foliar application with N, P and K, potassin and some fungicides on growth, sex expression, yield, chemical composition and disease severity of powdery mildew of squash plants .

\section{MATERIALS AND METHODS}

\section{Effect of foliar fertilizers on conidia germination In vitro}

The tested foliar fertilizer treatments N, P and K at 6 levels i.e 100, 200, $300,400,600$ and 800 ppm were used as follow:-

1 - Urea $(46 \% \mathrm{~N})$

2 - Calcium supper phosphate $\left(15.5 \% \mathrm{P}_{2} \mathrm{O}_{4}\right)$

3 - Potassium sulphate $\left(48 \% \mathrm{~K}_{2} \mathrm{O}\right)$

4 - Potassien - N $\left(30 \% \mathrm{~K}_{2} \mathrm{O}+8 \% \mathrm{~N}\right)$

5 - Potassien $-\mathrm{F}\left(30 \% \mathrm{~K}_{2} \mathrm{O}+10 \% \mathrm{P}_{2} \mathrm{O}_{3}\right)$ 
The treatment were either individually applied or in combination using $\mathrm{N}$ or $\mathrm{P}$ or $\mathrm{K}$ or $(\mathrm{N}+\mathrm{P}+\mathrm{K})$ or potassin- $\mathrm{F}$. The fungicides Topase $(0.25 \mathrm{~g} / \mathrm{l})$ and the micronized sulpher $(2.5 \mathrm{gm} / \mathrm{l})$ as show in table (1).

Table (1) :- Foliar fertilizers and fungicides treatments.

\begin{tabular}{|c|c|c|}
\hline Treatments & $\begin{array}{l}\text { Concentration of fertilizers and } \\
\text { fungicides }\end{array}$ & Nutrient content \\
\hline $\begin{array}{l}\text { Control } \\
\text { Urea (U) } \\
\text { Calcium super phosphate(CSP) } \\
\text { Potassium sulphate(PS) } \\
\text { U + CSP + PS } \\
\text { Potassin-N } \\
\text { Potassin-F } \\
\text { Topase } 200 \\
\text { Micronized Sulphur }\end{array}$ & $\begin{array}{c}\text { Without foliar fertilizer (tap water) } \\
1 \%(10 \mathrm{gm} / \mathrm{l}) \mathrm{w} / \mathrm{v} \\
1 \%(10 \mathrm{gm} / \mathrm{l}) \mathrm{w} / \mathrm{v} \\
1 \%(10 \mathrm{gm} / \mathrm{l}) \mathrm{w} / \mathrm{v} \\
1 \% \mathrm{U}+1 \% \mathrm{CSP}+1 \% \mathrm{PS} \\
30 \% \mathrm{~K}_{2} \mathrm{O} \text { and } 8 \% \mathrm{~N}(2.5 \mathrm{ml} / \mathrm{l}) \\
30 \% \mathrm{~K}_{2} \mathrm{O} \text { and } 10 \% \mathrm{P}_{2} \mathrm{O}_{5}(2.5 \mathrm{ml} / \mathrm{l}) \\
0.25 \mathrm{ml} / \mathrm{l} \text { (the recommended dose) } \\
2.5 \mathrm{gm} / \mathrm{l} \text { (the recommended dose) }\end{array}$ & $\begin{array}{c}46 \% \mathrm{~N} \text { as a source of } \mathrm{N} \\
15.5 \% \mathrm{P}_{2} \mathrm{O}_{5} \text { as a source of } \mathrm{P} \\
48 \% \mathrm{~K}_{2} \mathrm{O} \text { as a source of } \mathrm{K} \\
\text { as a source of } \mathrm{N}, \mathrm{P} \text { and } \mathrm{K} \\
\text { as a source of } \mathrm{K} \text { and } \mathrm{N} \\
\text { as a source of } \mathrm{K} \text { and } \mathrm{P} \\
10 \% \text { penconozale } \\
80 \% \text { Sulphur }\end{array}$ \\
\hline
\end{tabular}

U:- Urea CSP :- Calcium superphosphate PS :- Potassium sulphate

Each solution of the foliar fertilizers was deposited by means of hand atomizer on clean dry glass slides. The deposited solution was air dried to thin film and subsequently, the conidia were dusted on the slides by a camel hair brush. Each two slides were placed on Petri-dish containing mosited filter paper. Glass slides treated with distilled water left to dry and then dusted with conidia to serve as control . Four replicates were used for each particular concentration. All the slides were incubated for 24 hour at $25 \mathrm{C}^{\circ}$ and germination of conidia and the germ tube length were calculated .

Field experiments:

Two field experiments were carried out at the farm of EL. Goemmeiza Agric . Res station, Gharbiya government during the two succeive summer seasons of 2004 and 2005. The experimental soil was clay with PH 8.1 (in 1 : 2.5 suspension ) , $1.5 \%$ organic matter . Available N, P and K were $30,7.5$ and $450 \mathrm{ppm}$ in first season and 35, 7 and 465 in the second one, respectively. Seeds of squash variety "Eskandrani" were shown on $10^{\text {th }}$ and $16^{\text {th }}$ April of 2003 and 2004 , respectively . The experiment consisted of 9 treatments as shown in table 1 . These trails were arranged as complete randomized blocks design with 3 replicates. The plot area was $16 \mathrm{~m}^{2}$, consisted of 4 ridges $0.8 \mathrm{~m}$ apart and $5 \mathrm{~m}$ long. The distance between plants were $35 \mathrm{~cm}$. Thinning took place after complete germination i.e, two weeks after seed sowing, leaving one plant per hill. The usual agricultural procedures of squash were used, nitrogen fertilizer was added as Urea (46\% $\mathrm{N})$ at the rate of $60 \mathrm{Kg} / \mathrm{fed}$. in two equal dose befor the first and second irrigation. Meanwhile all plots were fertilized with $100 \mathrm{Kg}$ calcium super phosphate $\left(15.5 \% \mathrm{P}_{2} \mathrm{O}_{5}\right)$ before the first irrigation. Foliar application was made at the 2-3 true leaf stage for the first spray and the second was applied 7 days later , using spray solution at 200 liter / feddan with a knapsok sprayer , equipped with on nezool boom . 


\section{Vegetative growth :}

Five plants were collected from each plot to determine 1) vegetative growth, number of leaves, plant height and plant fresh weight after 100 days from sowing . 2) Flowering characters, five plants from each plot were chosen and labeled for the present study, male $(M)$ and female $(F)$ flowers for each treatment were counted two days intervals up to the end of the season.

\section{Sex expression :}

Sex ratio $(M / F)$ and femalness $F /(F+M)^{*} 100$ were determined , 3$)$. Yield and its components :

Yield parameters ; number of fruits / plant, average fruit weight (gm), early yield (ton / fed) was determined from the first six harvesting and total yield (plot) was determined by summation all harvests through out the season , and the yield calculated as (ton / fed).

\section{Chemical composition :}

Dry matter sample of petioles and blades of leaves were taken after 45 days from sowing and dried at $70 \mathrm{C}^{\circ}$ until constant weight, Total nitrogen was determined according to chapman and pratt (1978). Pand k were determined according to Jackson (1973). The data were statistically analaysed according to the procedure described by Snedecor and Cochran (1980) .

Disease severity :

Disease severity percentage was recorder on all plants of each plot and calculated according to the devised scale Horsfall and Barratt (1945).

\section{RESULTS AND DISCUSSION}

\section{Effect of foliar fertilizer on conidia germination :}

Table (2) show decrease in germination as well as in the length of germ tube by increasing the concentration of the fertilizers. The most efficient treatment was the fungicide treatment as Topase showed no conidia germination at ( 400 and $800 \mathrm{ppm}$ ) also unable to germinate under the effect of the micronized sulphur at the rate of $(800 \mathrm{ppm})$. The other treatments differed in their effect on the conidia germination and length of germ tube .At the highest concentration $(800 \mathrm{ppm})$ the (potassin P) gave $(18.3 \% \& 19.2 \mu)$ N P K resulted in $(19.9 \%$ \& $21.6 \mu), \mathrm{K}$ induced $(20.5 \%$ \& $24.3 \mu)$ and $\mathrm{P}$ showed $(22.6 \% \& 29.4 \mu)$ while $\mathrm{N}$ was the least effective which resulted in $(36.4 \% \& 40.1 \mu)$ as compared with control $(67.6 \% \& 74.2 \mu)$. This variation many treatments may be due to its highly toxicity and active ingredient. These results are in the line with that reported by Bains and Jhooty (1978) and El_desouky (1996), They concluded in general most of the un balanced treatment (NPK) reduced infection and sporylation of downy mildew. Suhag et al (1988) who found that the fungicide was more effective in controlling powdery mildew epidemics caused by Peseudoperonospora cubensis and it exhibited some phytotoxic effects.

\section{Disease severity:}

Table (3) indicate that all tested treatments exhibited lower disease severity in both growing season (2004) and (2005) Application of the 
fungicide in the first season (2004), Topase showed the lowest percentage of infection $(10.02 \%)$, followed by the micronized sulphur (16.12\%). Similar trend could be observed at potassin $(F)$, macroelemets in combination (N P $\mathrm{K})$, potassium sulphate and calcium super phosphate, while potassin $(\mathrm{N})$ $(22.14 \%)$. Application of Urea, however was the least effective treatment (28.24\%) when compared as control (63.65\%) infection. The results obtained with season (2004) were more similar to those of season (2005). The aim of fertilizer application was increase the natural fitness of cucurbits plants to the disease infection. These results are in agreement with those obtained by Farahat et al . (1990), El_desouky (1996) and Elkafrawy (1997) stated that, application ofphosphatic or potassic fertilizers did not affect of the powdery mildew disease of Pea. However, when both fertilizers were combined the percentage of mildew decreased and the yield was increasing.

Table (2) :- Effect of different concentration of the treatments on E.cichoracearum , conidia germination (\%) and germ tube length $(\mu)$.

\begin{tabular}{|c|c|c|c|c|c|c|c|c|c|c|c|c|c|c|c|c|}
\hline \multirow{3}{*}{ Treatments } & \multirow{2}{*}{\multicolumn{2}{|c|}{ Control }} & \multicolumn{12}{|c|}{ Concentration (PPm) } & \multirow{2}{*}{\multicolumn{2}{|c|}{ Mean }} \\
\hline & & & \multicolumn{2}{|c|}{25} & \multicolumn{2}{|c|}{50} & \multicolumn{2}{|c|}{100} & \multicolumn{2}{|c|}{200} & \multicolumn{2}{|c|}{400} & \multicolumn{2}{|c|}{800} & & \\
\hline & $\mathbf{G}$ & GTL & $\mathbf{G}$ & GTL & $\mathbf{G}$ & GTL & $\mathbf{G}$ & GTL & $\mathbf{G}$ & GTL & $\mathbf{G}$ & GTL & $\mathbf{G}$ & GTL & $\mathbf{G}$ & GTL \\
\hline Urea $1 \%$ & 67.6 & 74.2 & 65.9 & 72.8 & 63.8 & 71.3 & 59.9 & 69.4 & 50.1 & 61.2 & 43.5 & 53.1 & 36.4 & 40.1 & 53.9 & 61.3 \\
\hline $\begin{array}{l}\text { Calcium super } \\
\text { phosphate1\% }\end{array}$ & 67.6 & 74.2 & 62.2 & 70.4 & 60.6 & 68.4 & 53.5 & 65.1 & 46.7 & \begin{tabular}{|l|}
59.1 \\
\end{tabular} & 36.2 & 48.6 & 22.6 & 29.4 & 46.9 & 56.8 \\
\hline $\begin{array}{l}\text { Potassium } \\
\text { sulphate 1\% }\end{array}$ & 67.6 & 74.2 & 61.9 & 71.3 & 58.4 & 67.8 & 50.4 & 62.8 & 43.2 & \begin{tabular}{|l|l|}
51.4 \\
\end{tabular} & 33.8 & 40.2 & 20.5 & 24.3 & 44.7 & 52.9 \\
\hline U+CPS+PS 1\% & 67.6 & 74.2 & 60.7 & 70.2 & 55.7 & \begin{tabular}{|l|}
65.9 \\
\end{tabular} & 48.3 & 59.6 & 40.8 & \begin{tabular}{|l|}
46.6 \\
\end{tabular} & 30.2 & 38.3 & 19.9 & 21.6 & 42.6 & 50.3 \\
\hline $\begin{array}{l}\text { Potassin N) } 2.5 \\
\mathrm{ml} / \mathrm{I}\end{array}$ & 67.6 & 74.2 & 62.8 & 70.9 & 60.3 & 68.3 & 51.2 & \begin{tabular}{|l|}
63.1 \\
\end{tabular} & 42.7 & \begin{tabular}{|l}
54.3 \\
\end{tabular} & 31.1 & \begin{tabular}{|l}
43.5 \\
\end{tabular} & 21.4 & 27.1 & 44.9 & 54.5 \\
\hline $\begin{array}{l}\text { Potassin () } 2.5 \\
\mathrm{ml} / \mathrm{l}\end{array}$ & 67.6 & 74.2 & 61.6 & 70.1 & 56.8 & 64.8 & 49.5 & 58.9 & 39.8 & 42.6 & 29.2 & 36.4 & 18.3 & \begin{tabular}{|l|}
19.2 \\
\end{tabular} & \begin{tabular}{|l|}
42.1 \\
\end{tabular} & 48.6 \\
\hline \begin{tabular}{|l|} 
Micronised \\
Sulphur 2.5 \\
ml/l
\end{tabular} & 67.6 & 74.2 & 59.2 & 69.0 & 52.9 & 62.5 & 43.2 & 52.7 & 32.6 & 31.2 & 14.1 & 12.6 & --- & --- & 36.3 & 39.5 \\
\hline $\begin{array}{|ll|}\text { Topase } & (200) \\
0.25 \mathrm{ml} / \mathrm{l} & \\
\end{array}$ & 67.6 & 74.2 & 55.4 & 61.3 & 50.3 & \begin{tabular}{|l|}
61.2 \\
\end{tabular} & 40.1 & 49.9 & 15.2 & \begin{tabular}{|l|}
11.5 \\
\end{tabular} & --- & --- & --- & --- & 30.9 & 35.6 \\
\hline
\end{tabular}

G :- Germination( \%)

GTL :- Germ tube length $(\boldsymbol{\mu})$

U:-Urea CPS:- Calcium super phosphate

PS:- Potassium sulphate

Table (3) :- Effect of different treatment on powdery mildew severity (\%) of squash during $2004 \& 2005$ seasons.

\begin{tabular}{|l|c|c|}
\hline \multirow{2}{*}{ Treatments } & \multicolumn{2}{|c|}{ Disease severity } \\
\cline { 2 - 3 } & Season 2004 & Season 2005 \\
\hline Control & 63.65 & 55.86 \\
Urea 1\% & 28.24 & 26.35 \\
Calcium superphosphate 1\% & 20.96 & 19.18 \\
Potassium sulphate 1\% & 19.78 & 18.95 \\
U + CPS + PS 1\% & 18.14 & 17.25 \\
Potassin-N 2.5 mI/I & 22.14 & 21.50 \\
Potassin-F 2.5mI/I & 18.95 & 18.17 \\
Topase (200) 0.25 mI/I & 10.02 & 8.97 \\
Micronized sulphur 2.5 ml/I & 16.12 & 15.04 \\
\hline L.S.D at 5\% & $\mathbf{5 . 0 1}$ & $\mathbf{3 . 1 1}$ \\
\hline
\end{tabular}

U:-Urea CPS:- Calcium super phosphate

PS:- Potassium sulphate

Vegetative growth : 
Data of table (4) show the effects of different fertilizers. Compounds and some fungicides, added as foliar spary to squash plants, on some growth parameters . Number of leaves per plant, plant height plant fresh weight and plant dry weight were responded to the foliar treatments. The effects were significant in both seasons The highest values were obtained from spraying squash plants with Urea, potassium sulphate Urea + calcium super phosphate + potassium sulphate, potassien N . Topas and sulpher, while, The leavest values were obtained from control, cacium super phosphate and potassin-F .Spraying squash plants with Topase gave the highest values of numbers of leaces and plant height. Moreover, foliar spray with sulpher micromized gave the highest values of fresh and dry weight plant. Foliar feeding with N P K caused on increase in growth can be attributed to two main reasons. First is high demand of N P K , the second reason and perhaps the more important, N P K can be taken up rapidly and metabolised by leaves especially at period of high demand during fruit development . This result may statisfactorily agree with Elsayed et al , (1992) on squash and Mohamed et al , (1999) on cawpea . Morover, last and Nour (1961) found that phosphorus and potassium foliar fertilizers increased the average yield of vicia faba crop twice as high as the unsprayed. Foliar application with fungicides increased significantly growth of squash plants . This may be due to the complete protection from powdery mildew with this treatment which prolonged life of plants. Similar results were obtained by , Abdel . Hafez and Abd EL.Gawad (1987) on squash . Also, Ismail et al, (2000) they found that Topas and sulpher increased significantly dry weight of squash plants. It can be concluded that foliar N P K and potassin-N of squash plants has a favourable effect on the studied parameters of vegetative growth . Hanafy Ahmed (1997) found that foliar application of squash plants with Urea, calcium super phosphate and potassium sulphate increased dry weight, Free amino acid, sugars and N P K in dry weight .

Table (4) :- Effect of foliar application with N, P, K, potassin and some fungicides on vegetative growth of squash after 70 days from sawing during 2003 and 2004 seasons.

\begin{tabular}{|c|c|c|c|c|c|c|c|c|}
\hline \multirow[t]{2}{*}{ Treatments } & \multicolumn{2}{|c|}{$\begin{array}{l}\text { No of leaves } \\
\text { /plant }\end{array}$} & \multicolumn{2}{|c|}{$\begin{array}{l}\text { Plant height } \\
\text { (Cm) }\end{array}$} & \multicolumn{2}{|c|}{$\begin{array}{l}\text { Plant fresh } \\
\text { weight }(\mathrm{Kg})\end{array}$} & \multicolumn{2}{|c|}{$\begin{array}{c}\text { Plant dry } \\
\text { weight (g) }\end{array}$} \\
\hline & 2004 & 2005 & 2004 & 2005 & 2004 & 2005 & 2004 & 2005 \\
\hline Control (tap water) & 27.67 & 28.66 & 31.67 & 29.33 & 1.033 & 0.967 & 95.3 & 90.6 \\
\hline Urea $1 \%$ & 39.67 & 38.00 & 39.67 & 35.33 & 1.833 & 1.833 & 156.17 & 175 \\
\hline Calcium superphosphate $1 \%$ & 33.00 & 38.33 & 35.00 & 34.33 & 1.500 & 1.600 & 133.65 & 145 \\
\hline Potassium sulphate 1\% & 41.67 & 39.33 & 41.67 & 35.66 & 2.067 & 1.967 & 185.5 & 160 \\
\hline $\mathrm{U}^{*}+\mathrm{CSP}+\mathrm{PS} 1 \%$ & 41.67 & 39.33 & 43.67 & 36.00 & 1.767 & 1.833 & 162.7 & 166.15 \\
\hline Potassin-N $2.5 \mathrm{ml} / \mathrm{l}$ & 46.00 & 46.66 & 42.67 & 37.67 & 1.733 & 1.867 & 161.9 & 172.6 \\
\hline Potassin-F $2.5 \mathrm{ml} / \mathrm{l}$ & 35.00 & 33.66 & 35.00 & 37.67 & 1.467 & 1.233 & 138.0 & 115.5 \\
\hline Topas $0.25 \mathrm{ml} / \mathrm{l}$ & 49.00 & 41.67 & 47.33 & 50.67 & 1.733 & 1.567 & 147.2 & 147.15 \\
\hline Sulphur $2.5 \mathrm{gm} / \mathrm{l}$ & 37.00 & 40.00 & 41.67 & 49.33 & 1.900 & 1.867 & 175.8 & 174.17 \\
\hline L.S.D at $0.05 \%$ & 8.1 & 8.16 & 6.56 & 7.8 & 0.440 & 0.258 & 34.3 & 21.0 \\
\hline
\end{tabular}

\section{Sex expression :}


Data in table (5) show that , foliar application with potassium sulphate , potassin- $\mathrm{N}$ and sulpher gave the highest values of total flowers of squash plants in both seasons compared with control, Urea and calcium super phosphate, Moreover, the same data show clearly that all treatments significantly increased the percentage of female flowers, Unsprayed plants (control) produced the least of female flowers and the highest of male flowers . Moreover, data revealed that high significant increases in the percentage of femaleness as well as high significant decreases in sex ratio were reduced by the plants sprayed with all treatments compared with control-untreated plants . Spraying squash plants with Topase gave the highest values of femalness $\%$ in both seasons . In this respect Abdel. Hafez and Abd El-Gawad (1987) found that spraying squash plants with fungicide Mil carbo : $4 \%$ increased the percentage of female flower and decreased the sex ratio. Also, Hanafy Ahmed (1997) found that spraying squash plant with Urea-calcium super phosphate, potassium sulphate significantly increased number of female flowers resulted in high significant decreases in sex ratio he also found that these treatment gave the highest values of dry matter accumulation and content of different of organic (sugars and amino acids) and inorganic (N, P and $\mathrm{K}$ ). The increasing of female flowers may be due to high values of cytokimin activity Hanafy Ahmed (1997)

Table (5) :- Effect of foliar application with N, P, K, potassin and some fungicides on number of flowers ( male and female ), \% of femaleness and sex ratio of squash plants during 2003 and 2004 seasons.

\begin{tabular}{|c|c|c|c|c|c|c|c|c|}
\hline \multirow[t]{2}{*}{ Treatments } & \multicolumn{2}{|c|}{ Male flowers } & \multicolumn{2}{|c|}{$\begin{array}{l}\text { Female } \\
\text { flowers }\end{array}$} & \multicolumn{2}{|c|}{$\%$ of femaleness } & \multicolumn{2}{|c|}{ Sex ratio } \\
\hline & 2004 & 2005 & 2004 & 2005 & 2004 & 2005 & 2004 & 2005 \\
\hline Control (tap water) & 21.67 & 21.67 & 7.67 & 8.00 & 26.1 & 26.9 & 2.84 & 2.74 \\
\hline Urea $1 \%$ & 15.00 & 16.00 & 12.33 & 12.00 & 45.1 & 42.7 & 1.21 & 1.33 \\
\hline Calcium superphosphate & 18.00 & 17.00 & 10.33 & 11.67 & 36.4 & 40.7 & 1.75 & 1.45 \\
\hline Potassium sulphate $1 \%$ & 19.67 & 19.33 & 12.33 & 14.33 & 43.3 & 42.5 & 1.58 & 1.35 \\
\hline $\mathrm{U}^{\star}+\mathrm{CSP}+\mathrm{PS} 1 \%$ & 17.33 & 16.00 & 11.67 & 12.33 & 36.4 & 43.5 & 1.48 & 1.3 \\
\hline Potassin-N $2.5 \mathrm{mIV}$ & 16.00 & 19.00 & 15.00 & 13.33 & 48.3 & 41.6 & 1.10 & 1.41 \\
\hline Potassin-F $2.5 \mathrm{ml} \backslash$ & 21.00 & 18.67 & 15.33 & 14.33 & 51.6 & 43.4 & 1.36 & 1.290 \\
\hline Topase $0.25 \mathrm{mIV}$ & 19.33 & 16.67 & 16.67 & 13.67 & 56.8 & 45.00 & 1.16 & 1.403 \\
\hline Sulphur $2.5 \mathrm{gm} \backslash \mathrm{I}$ & 20.00 & 16.67 & 17.67 & 14.00 & 44.9 & 45.6 & 1.40 & 1.19 \\
\hline L.S.D at $0.05 \%$ & 2.82 & 1.96 & 1.67 & 1.25 & 3.07 & 3.1 & 0.263 & 0.263 \\
\hline
\end{tabular}

Yield and its components :

Data of table (6) show clearly that spraying squash plants with $\mathrm{N}, \mathrm{P}, \mathrm{K}$ , potassin and some fungicide increased significantly No . of fruits plant, average fruit weight, Early and total Yield (ton/fed) compared with controlunsprayed plants. The highest values were obtained from plants sprayed with solution of Urea $1 \%+$ calcium super phosphate $1 \%+$ potassium sulphate $1 \%$. The superiority of spraying squash plants with solution of Urea + calcium super phosphate + potassium sulphate could be attributed to its $\mathrm{N}$ $\mathrm{P} \mathrm{K}$ contents which helps giving plants some of its higher requirements of these essential elements as its clear in Table. In this respect, El . Sayed et 
al , (1992) working on squash mentioned that spraying with $\mathrm{KH}_{2} \mathrm{PO}_{4}$ at the concentration of $0.04 \% \mathrm{p}$ produced the highest yield. Moreover, Safia Adam et al (1998) working on tomato mentioned that spraying with $0.7 \% \mathrm{~N}+1.0 \%$ $\mathrm{K}_{2} \mathrm{O}$ gave more Yield of tomato plants, than these sprayed with each of solution spraying squash plants with potassium sulphate $1 \%+$ potassium $1 \%$ + sulphate $1 \%$ gave the highest values of vegetative growth i.e. No of leaves / plant, plant height, fresh and dry weight / plant compared with control . Moreover, significant increases in the number of female flowers per plant and percentage of femaleness were recorded by plants sprayed with Urea $1 \%$, calcium super phosphate $1 \%$, potassium sulphate $1 \%$, mixture of them , potassien- $\mathrm{N} 2.5 \mathrm{ml} / \mathrm{l}$, Topas $0.25 \mathrm{ml} / \mathrm{l}$ and sulpher $2.5 \mathrm{gm} / \mathrm{l}$ compared with control-unsprau plants .

Table (6) :- Effect of foliar application of N, P, K, potassin and some fungicides on fruit yield and its components of squash plants during 2003 and 2004 seasons.

\begin{tabular}{|c|c|c|c|c|c|c|c|c|}
\hline \multirow[t]{2}{*}{ Treatments } & \multicolumn{2}{|c|}{$\begin{array}{c}\text { No of } \\
\text { fruits/plant }\end{array}$} & \multicolumn{2}{|c|}{$\begin{array}{l}\text { Average fruit } \\
\text { weight (gm) }\end{array}$} & \multicolumn{2}{|c|}{$\begin{array}{l}\text { Early yield } \\
\text { (Ton/Fed.) }\end{array}$} & \multicolumn{2}{|c|}{$\begin{array}{l}\text { Total yield } \\
\text { (Ton/Fed.) }\end{array}$} \\
\hline & 2004 & 2005 & 2004 & 2005 & 2004 & 2005 & 2004 & 2005 \\
\hline Control (tap water) & 4.67 & 4.53 & 105.67 & 96.00 & 2.21 & 1.77 & 6.52 & 5.14 \\
\hline Urea $1 \%$ & 8.33 & 9.70 & 121.00 & 105.00 & 3.92 & 3.83 & 12.93 & 12.58 \\
\hline Calcium superphosphate & 7.83 & 7.67 & 118.00 & 114.00 & 3.70 & 3.93 & 11.85 & 10.72 \\
\hline Potassium sulphate $1 \%$ & 9.50 & 8.17 & 123.67 & 120.00 & 4.40 & 4.02 & 14.57 & 12.12 \\
\hline $\mathrm{U}^{*}+\mathrm{CSP}+\mathrm{PS} 1 \%$ & 9.87 & 9.33 & 130.33 & 130.67 & 4.61 & 4.38 & 15.2 & 15.11 \\
\hline Potassin-N $2.5 \mathrm{mI} \mathrm{I}$ & 8.83 & 8.00 & 130.67 & 123.00 & 4.65 & 3.47 & 15.58 & 12.24 \\
\hline Potassin-F $2.5 \mathrm{mI} \backslash \mathrm{I}$ & 7.93 & 6.967 & 123.33 & 117.00 & 3.72 & 3.63 & 11.64 & 10.2 \\
\hline Topas $0.25 \mathrm{mIVI}$ & 7.47 & 8.100 & 119.67 & 118.67 & 3.46 & 3.67 & 11.28 & 11.6 \\
\hline Sulphur $2.5 \mathrm{gm} \backslash$ & 7.77 & 8.167 & 124.00 & 121.67 & 3.6 & 3.51 & 11.87 & 12.45 \\
\hline L.S.D at $0.05 \%$ & 1.059 & 0.690 & 5.47 & 4.70 & 0.054 & 0.6 & 1.72 & 1.26 \\
\hline
\end{tabular}

Generally, The maximum number of fruit per plant, average fruit weight (gm) , Early and total Yield (ton/fed) were recorded with Urea 1\% + calcium super phosphate $1 \%$ + potassium sulphate $1 \%$ and potassien $-\mathrm{N}$ at $2.5 \mathrm{ml} / \mathrm{l}$ the individual or control. Also, Hanafy Ahmed (1997) found that spraying of squash plants with Urea, calcium super phosphate and potassium sulphate significantly increased fruit Yield of squash plants. The increasing of Yield Of squash fruits could be attributed to spraying withTopas and sulpher which led to control of powdery mildew and reduced severity disease.

\section{Chemical composition:}

Nitrogen concentration : Data in table (7) show that the foliar feeding of squash plants in different treatment used seemed to increase significantly $\% \mathrm{~N}$ in the dry matter of leaves during the two season of experimentation compared with control Regarding phosphorus with concentration, the foliar addition of different treatment used significantly affected P\% in dry matter of leaves in both seasons compared with control with respect to potassium concentration, the foliar addition of different treatments used increased $\mathrm{K} \%$ significantly in the dry matter of leaves. The data show clearly that the highest values of N P K concentrations were obtained from spraying squash plants with solution contain $1 \%$ Urea $+1 \%$ calcium supper phosphate + potassium sulphate compared with individual treatment or control. Similar 
results were obtained by Elsayed et al. (1992) and Hanafy Ahmed (1997) on squash plants.

Table (7) :- Chemical composition of squash leaves as effected by foliar spray with $N, P, K$, potassin and some fungicides.

\begin{tabular}{|l|c|c|c|c|c|c|}
\hline \multirow{2}{*}{ Treatments } & \multicolumn{2}{|c|}{ N\% } & \multicolumn{2}{c|}{ P\% } & \multicolumn{2}{c|}{ K\% } \\
\cline { 2 - 7 } & $\mathbf{2 0 0 4}$ & $\mathbf{2 0 0 5}$ & $\mathbf{2 0 0 4}$ & $\mathbf{2 0 0 5}$ & $\mathbf{2 0 0 4}$ & $\mathbf{2 0 0 5}$ \\
\hline Control (tap water) & 3.3 & 2.6 & 0.32 & 0.29 & 2.7 & 2.9 \\
Urea 1\% & 4.55 & 3.5 & 0.36 & 0.35 & 3.6 & 3.7 \\
Calcium superphosphate & 4.1 & 3.1 & 0.41 & 0.42 & 3.5 & 3.6 \\
Potassium sulphate 1\% & 4.55 & 3.3 & 0.38 & 0.35 & 3.8 & 4.6 \\
U $^{\star}+$ CPS + PS & 4.9 & 3.8 & 0.43 & 0.42 & 4.3 & 5.0 \\
Potassin (N) 2.5 mIVI & 4.55 & 3.9 & 0.39 & 0.37 & 4.6 & 4.8 \\
Potassin (F) 2.5 mIVI & 3.9 & 3.3 & 0.41 & 0.41 & 4.5 & 4.7 \\
Topas 0.25 mIII & 3.55 & 3.1 & 0.34 & 0.37 & 3.6 & 3.5 \\
Sulphur 2.5 gmVI & 3.55 & 3.2 & 0.37 & 0.37 & 3.5 & 3.6 \\
\hline L.S.D at 5 level & 0.26 & 0.34 & 0.06 & 0.04 & 0.43 & 0.54 \\
\hline U:-Urea
\end{tabular}

\section{REFERENCES}

Abd ElHafez , A . A and Mona M . El_Gawad (1987) : Effect of same fungicides on sex expression and Yield of squash and cucumber. Annals of agric . sci , Moshtohor, Vol . 25 (4) : $2280-2289$.

Amberger, A . (1993) : Dymamics of nutrients and reactions of retilizers applied on the environment proc . of Germany / Egyptian / Arab workshop in cairo and Ismalia, Egypt 6-17 June, 1993. Edited by $M$ . M. Fouly and $F-E$. Abdolla : $41-59$.

Bains , .S . and Jhooty, J.S .(1978 b) : Realationship between mineral nutrition of muskmelon and development of downy mildew caused by Psendoperonspora cubensis . plant and soil , $49: 85-90$.

Chopman , H . D . and P . P . Pratt (1978) : Methods of analysis for soils , plants and water . Univ of California, Div of Agric . Sci . priced publ . 40 -34 .

Curger, G (1974) : A.sever occurrence of downy mildew caused by pseudo peronosora cubensis on cucumber crops in the Rhimeland. Nachrichtenblatt des deutschen $p$ fcanzenschutzdienstes , 26 (10), 145 .

El_desouky, S.M . (1996) : Studies on downy mildew disease of cucurbits . Ph.D . Thesis, Fac . of Agric , Minufiya Univ . 89-94 .

El-Kafrawy (1997) : Studies on powdery mildew of pepper ph.D.Thesis, Agric , Menofiya Univ .

El- Nagar, M . A, Maklad , F . M , Ali , M . H . and Fadl , F . A (1991) : Downy mildew disease of cucumber in plastic houses and its control . Egypt . J . Appril . Sci . 6, 12 .

El-sayed, Hala A .; A . M . Abo Elkhear and K . H . El-Hamdi (1992) : Growth , Yield and chemical composition of squash plants (cucurbit apepol) as affected by phosphorus foliar application . 
Farahat A.A ;El-Shami, Mona A.; Fadl , F.A. and El-zayat , M.M .(1990) : Fungicidal application on the management of Pea powdery mildew in relation to Yield . Agric . Res . Rev ., 68 (3) . $501-512$.

Gruzdyen, G . S .(1980): The chemical protection of plants fungicides pp . $267-335$, MIR publishers Moscow .

Hanafy Ahmed, A . H .(1997) : Effect of foliar application of some chemicals on sex expression of squash plants . J . Agric . Sci . mansoura univ , 22 (3) : $697-717$

Horsfall ,J.G. and Barratt, R.W (1945) : An improved rating system for measuring plant diseases. Plant Pathology, 35:665.

Ismail , A . A ; E . A M . Hamada and M . A . Elhaak (2003) : Control of powdery mildew disease by some fungicides of different chemical groups and their side effect on squash. Egypt J . Agron . 25 , pp . 1 14 .

Jacson M . L . (1973) : Soil chemical analysis . prentice Hall of Indian private limited, New Delhi.

Javoraska, T . (1978). Effect of combined herbicides on the occurrence of morphoses in the spikes of spring barly. Agrochemia , 18:37-42.

Last , F . T . and M . A Nour (1961) : Cultivation of (vicia faba I .) in northern sudan . Emp . J . Exp . Agric . 29 (113) : 60 - 70 . (c . f . field crop Abst $.14: 1227)$.

Maximilian . K.; E . Muhle ; E. Renmuth and H.Bochow (1976) : Phytopathologie and phlanzenschutz . Akademic .Verly . Berlin , 915 $\mathrm{pp}$.

Mengle , K . and E . Kirkiby (1987) : Principals at plant nutrition . International potash Instilue P . O . Box . CH . 3048 worblan fen - bern, Switzerland

Mohamed , F . I F F . A . Helal and A . Y . El_Taweel (1999) : Response of growth, seed Yield and its components and seed chemical conistituents in some cawpea CVS . To foliage nutrition . Zagozid $\mathrm{J}$. Agric . RES . vol 26 No . (4) : $1125-1135$.

Safia, M . Adam , E . H . Abou El . Saleheen and A . M . Abd - Alla (1996) : Effect of $\mathrm{N}$ and $\mathrm{K}$ fertilizers as foliar spray on Tomatoes under green house conditions . Zagazig J . Agric . Res . Vol . 23 No (4) . $629-640$.

Snedecor , G . W . and W . G. Cochran (1980): Methods. The . lowa state Univ . Pros . Amer . USA . 7 th ed.

Sommro B . A (1997) : Cotton fertilization in Pakistan . FAO_IRCRNC, Joint Meeting of the working Groups 384 (cotton nutrition \& Growth Regulators) ; $20-23$ March, 1995 , cairo Egypt pp . $51-57$.

Suhag, L.S , Maheshwari , S.K and Duhan , J.C (1988) : Chemical control of Pesudopronospora cubensis causing downy mildew on sponge gourd . Indian Journal of Agric . Sciences , 58 (6) : 462-464.

Wilson , Ch .; Fanklin , J.D. and Otto , B.E .(1987). Fruit volatives inhibitory to Monilinia frueticola ana Botrytis cinerea Plant DIS ., 71(4) . 316-319. 
" تاثير الرش ببعض الاسمدة والكيماويات علنالنمو والمحصول في الكوسـة وعلاقة

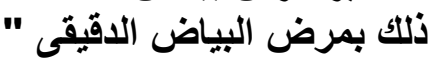

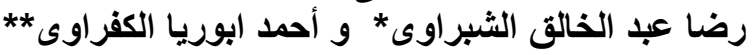

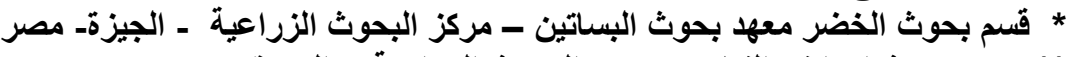

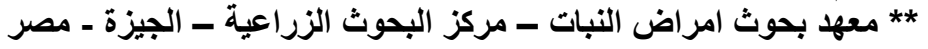

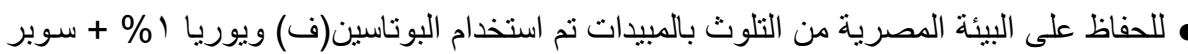

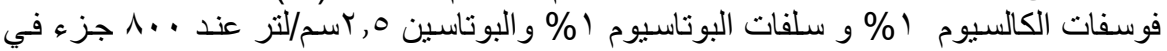

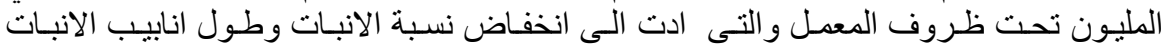

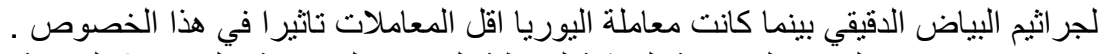

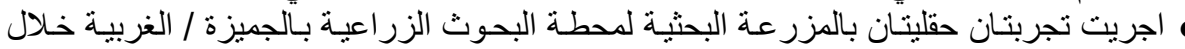

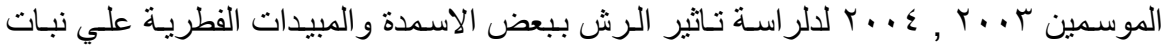

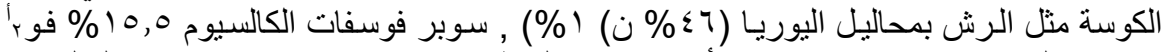

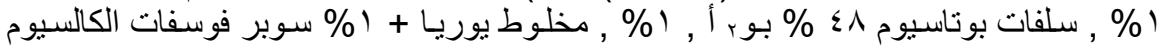

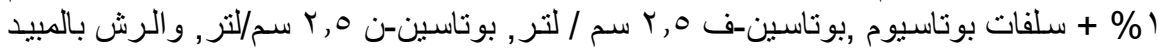

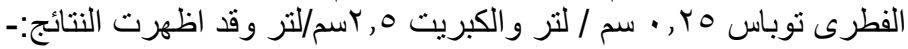

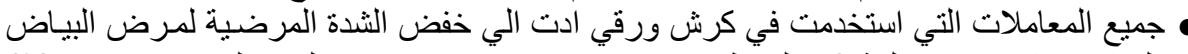

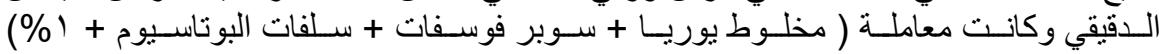

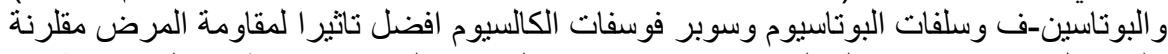

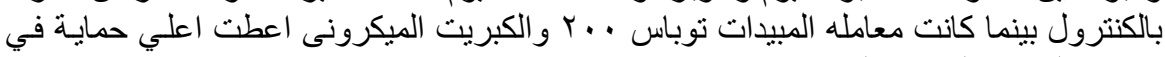

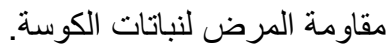

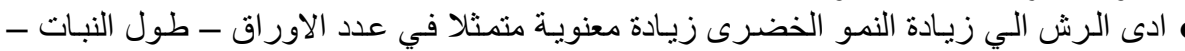

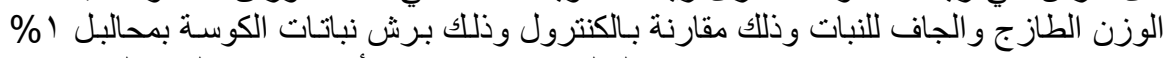

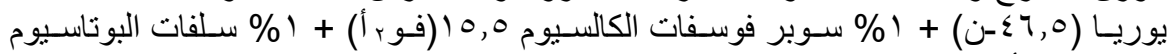

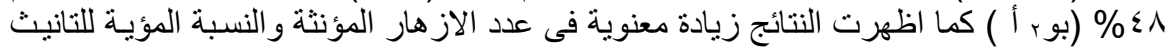

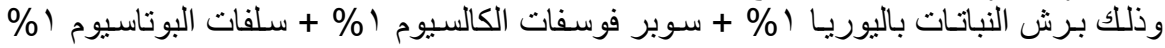

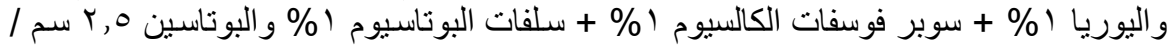

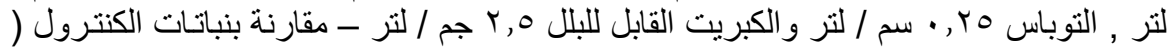

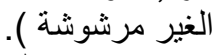

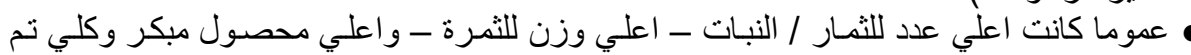

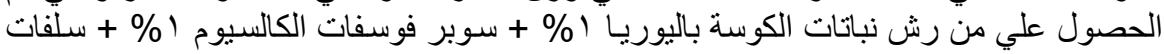

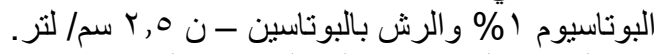

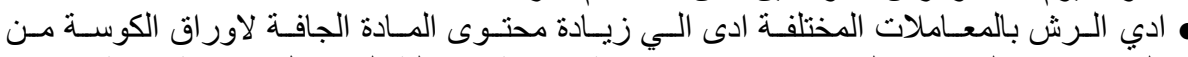

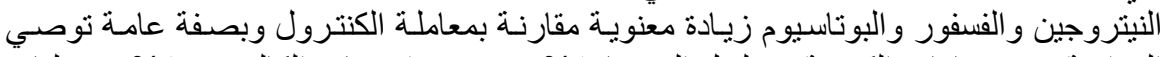

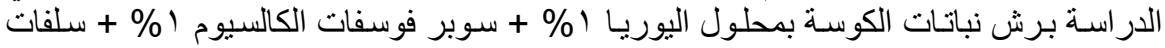

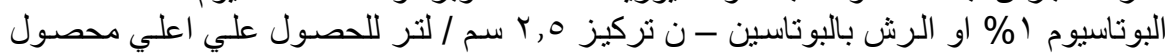

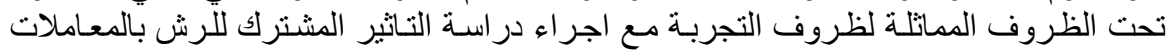

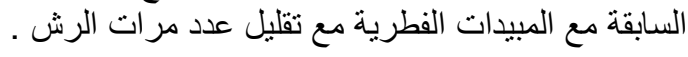


El-Shabrawy, R. A. and A. A. El-Kafrawy

El-Shabrawy, R. A. and A. A. El-Kafrawy

El-Shabrawy, R. A. and A. A. El-Kafrawy

El-Shabrawy, R. A. and A. A. El-Kafrawy

El-Shabrawy, R. A. and A. A. El-Kafrawy

El-Shabrawy, R. A. and A. A. El-Kafrawy

El-Shabrawy, R. A. and A. A. El-Kafrawy

El-Shabrawy, R. A. and A. A. El-Kafrawy

El-Shabrawy, R. A. and A. A. El-Kafrawy

El-Shabrawy, R. A. and A. A. El-Kafrawy

El-Shabrawy, R. A. and A. A. El-Kafrawy

El-Shabrawy, R. A. and A. A. El-Kafrawy 
J. Agric. Sci. Mansoura Univ., 32 (3), March, 2007

El-Shabrawy, R. A. and A . A . El-Kafrawy

El-Shabrawy, R. A. and A . A . El-Kafrawy

El-Shabrawy, R. A. and A . A . El-Kafrawy

El-Shabrawy, R. A. and A . A . El-Kafrawy

El-Shabrawy, R. A. and A . A . El-Kafrawy

El-Shabrawy, R. A. and A . A . El-Kafrawy

El-Shabrawy, R. A. and A . A . El-Kafrawy

El-Shabrawy, R. A. and A . A . El-Kafrawy

El-Shabrawy, R. A. and A . A . El-Kafrawy 